\title{
Genetic analysis and molecular mapping of stripe rust resistance genes in Chinese native wheat (Triticum aestivum) Lankao 5
}

\author{
Q. Yao ${ }^{1,2}$ • M. M. He ${ }^{1,2}$ - L. Hou ${ }^{2}$ J. H. Yan $^{2}$ • Q. Y. Guo ${ }^{2}$ J. X. Jing ${ }^{1}$ - Z. S. Kang ${ }^{1}$
}

Received: 2 December 2016 / Accepted: 1 March 2017 / Published online: 5 April 2017

(C) The Author(s) 2017. This article is published with open access at Springerlink.com

\begin{abstract}
Lankao 5 is a common wheat (Triticum aestivum) landrace collected from Henan province, China, which exhibits a high level of resistance to stripe rust (Puccinia striiformis f.sp. tritici, 'Pst') in field trials over many years. To analysegenetic of resistance in Lankao $5, \mathrm{~F}_{1}$ and $\mathrm{F}_{2}$ progenies were obtained from a cross between wheat genotypes Lankao 5 and Chinese Spring (CS). Parents, $F_{1}$ and $F_{2}$ plants, were planted in greenhouse and tested at the seedling stage with Pst races CYR29, CYR30, CYR31, CYR32, Sun11-4, and Sun11-11. Genetic analysis showed that the resistance of Lankao 5 to race CYR30 were conferred independently all by one dominant gene and one recessive gene, independently, resistance to Sun11-11 by one dominant gene, resistance to CYR31, CYR32, and Sun11-4 all by two independent dominant genes, and resistance to CYR29 by two recessive genes of independent action. Using $\mathrm{F}_{2}$ progenies from crosses between Lankao 5 and a set of 20 CS monosomic lines, the resistance gene in Lankao 5 to Pst race Sun11-11 was cytogenetically located on chromosome $7 \mathrm{~B}$. Using $141 \mathrm{~F}_{2}$ plants and
\end{abstract}

Qiang Yao and Miaomiao He made equal contributions to this study.

Q. Y. Guo

guoqingyunqh@163.com

Z. S. Kang

kangzs@nwsuaf.edu.cn

1 State Key Laboratory of Crop Stress Biology for Arid Areas, College of Plant Protection, Northwest A\&F University,

Yangling, Shaanxi 712100, China

2 State Key Laboratory of Plateau Ecology and Agriculture/Qinghai Academy of Agriculture and Forestry Science/Scientific Observing and Experimental Station of Crop Pest in Xining, Ministry of Agriculture/Key Laboratory of Agricultural Integrated Pest Management, Qinghai University, Xining, Qinghai 810016, China their $\mathrm{F}_{3}$ generations with $7 \mathrm{~B}$ specific simple sequence repeat (SSR) markers, a linkage map consisting of five SSR loci and the resistance gene locus $Y r L k$ was constructed. The linkage map spanned a genetic distance of $21.6 \mathrm{cM}$, and the SSR markers Xwmc396 and Xbarc267 were closely linked to $Y r L k$ with genetic distances of 3.3 and $4.4 \mathrm{cM}$, respectively. Analyses of chromosomal positions, reaction types to Pst race, and gene origin suggested that $Y r L k$ was very likely a novel resistance gene for stripe rust in wheat. Genetic analysis of the stripe rust resistance gene in Lankao 5 and closely linked markers for $Y r L k$ will facilitate the use of resistance in breeding programs to control wheat stripe rust.

Keywords Stripe rust $\cdot$ Puccinia striiformis $\cdot$ Resistance gene mapping $\cdot$ Genetic analysis $\cdot$ Wheat $\cdot$ Triticum aestivum

\section{Introduction}

Wheat stripe rust (yellow rust), an airborne disease caused by Puccinia striiformis f. sp. tritici (Pst), is one of the most damaging diseases of wheat (Triticum aestivum L.) worldwide (Chen 2005; Wellings 2011). In China, the disease occurs annually in most wheat growing areas, especially in northwest, southwest, and the Huang-Huai wheat production region, which is considered as the largest stripe rust epidemiologic region in the world (Wan et al. 2007). Although the use of fungicides can prevent the disease, the application of fungicides adds a significant extra cost to farmers. The chemicals may cause adverse effects to the environment and may not be fully effective if missing the best application time. Growing resistant cultivars is the most effective, environmentally sound, economic, and consistently used method of controlling stripe rust. To improve stripe rust resistance, two types of resistance are generally used in wheat breeding programs. 
One type is race specific, also known as all-stage resistance, and the other is non-race specific or adult plant resistance. Allstage resistance expresses from seedling through all developmental stages of wheat, facilitates breeding selection, and is widely employed in wheat cultivars. However, race-specific resistance can be easily overcome by new virulent races, due to the high variability of the stripe rust pathogen, resulting in rust epidemics (Li and Zeng 2002; Line 2002). Adult plant resistance is durable but may not be adequate when rust infection is too severe. Both resistance types need to be combined to attain the better disease control (Chen 2005). With the variation of Pst virulence, the resistance genes in the majority of breeding programs in China have varied at least eight times since the first nation-wide stripe rust epidemics in the 1950s (Hou et al. 2013; Li and Zeng 2002; Wan et al. 2003, 2007). In the past decade, resistance in wheat cultivars Hybrid 46, Suwon 11, and ' $Y r 24$ ' were overcome by the predominant Pst races, and only a few resistance genes are effective against the current Chinese Pst population (Cheng et al. 2006; Han et al. 2010, 2012; Wan et al. 2003; Wang et al. 2007). The need is great to identify new, effective resistance genes for breeding programs in stripe rust epidemic areas, such as Sichuan, Yunnan, Shaanxi, and Gansu, China (Wan et al. 2004; Cheng et al. 2006; Yang et al. 2003).

Landraces constitute a valuable genetic resource, possessing various desirable agronomic traits, including high-level resistance to wheat stripe rust. In the 1950s, Prof. Zhao used a Chinese landrace Maza crossed with an elite cultivar Biyu to develop a set of wheat cultivars with good resistance to stripe rust in China (Li and Zeng 2002; Wan et al. 2007). However, the landrace has some poor agronomic traits, requiring an extended period for selective introgression of desirable traits through the breeding process. In the past several decades, molecular techniques have provided useful tools for modern wheat breeding. Identification of molecular markers associated with resistance genes then using these markers in breeding process will facilitate successful selection. Molecular markers have been developed for many stripe rust resistance genes, such as $\mathrm{Yr} 5, \mathrm{Yr} 10, \mathrm{Yr} 15, \mathrm{Yr} 26, \mathrm{Yr} 45$, Yr53, Yr64, and Yr65 (Yan et al. 2003; Wang et al. 2002; Li et al. 2011; Wang et al. 2008; Xu et al. 2013; Yaniv et al. 2015; Cheng et al. 2014). Among the molecular markers, simple sequence repeat (SSR) marker is most widely utilized in wheat disease resistance gene mapping and genetic improvement, due to its high polymorphism, repeatability, and low cost (Li et al. 2009; Ren et al. 2010; Wang et al. 2009; Zhang et al. 2010; Cheng et al. 2014).

Lankao 5, a wheat landrace collected in Henan province of China, showed a high-level resistance to stripe rust in our field trials over many years. In this study, we analyzed the resistance inheritance of Lankao 5 to the prevalent races in the Chinese Pst population and constructed a genetic map of the stripe rust resistance gene in Lankao 5 with SSR markers using $F_{1}$ plants and $F_{2: 3}$ populations from cross of Lankao 5 and Chinese Spring. These findings will be important for understanding the genetic basis of rust resistance in Lankao 5 and for using marker-assisted selection to transfer this resistance gene to other wheat cultivars in improving control of wheat stripe rust.

\section{Materials and methods}

\section{Plant and pathogen materials}

Lankao 5 is a wheat landrace collected from Henan province of China, which is resistant to most races of stripe rust in China. Chinese Spring (CS) is a wheat germplasm susceptible to all Pst races at the seedling stage. Lankao 5 was crossed with CS and a set of 21 monosomic CS lines (3D monosomic line was absent in further analyses due to $F_{1}$ failed to produce $\mathrm{F}_{2}$ seeds). Chinese Spring monosomic lines and $\mathrm{F}_{1}$ plants were confirmed cytologically using the Feulgen staining method (Xu et al. 2013). For each of the 21 crosses, the $F_{1}$ plants were selfed to develop $F_{2}$ populations; then, the $F_{2}$ plants were grown to maturity and harvested for $\mathrm{F}_{2: 3}$ seeds. The seeds of parents, $F_{1}, F_{2}$, and $F_{2: 3}$ generations, were propagated in a controlled greenhouse.

Six predominant Chinese Pst races (Chen et al. 2009; Li et al. 2016), Sun11-4, Sun11-11, CYR29, CYR30, CYR31, and CYR32, were used to test Lankao 5, CS, and $F_{1}$ plants and $\mathrm{F}_{2}$ populations of $\mathrm{CS}$ monosomic lines at the seedling stage in greenhouse.

\section{Seedling tests}

Each $\mathrm{F}_{2}$ population from crosses between Lankao 5 and the 20 CS monosomic lines were tested in parallel with race Sun1111 to analyze the chromosome location of the resistance gene in Lankao 5. $\mathrm{F}_{2: 3}$ generations from Lankao5 $\times$ CS 1D monosomic which were selected to construct a genetic linkage map were tested with race Sun11-11.

Seedling tests were conducted under controlled greenhouse conditions. About 15 seeds from each parent and $F_{1}$ generations, about 200 seeds from each $\mathrm{F}_{2}$ population, and 20 seeds from each of the $\mathrm{F}_{3}$ lines were used for tests. Fifteen to 20 seeds were planted per $10 \mathrm{~cm}$ diameter $\times 12 \mathrm{~cm}$ deep pot. Plants were grown at day/night temperatures of $25 / 15^{\circ} \mathrm{C}$ and day/night lights of $16 / 8 \mathrm{~h}$ cycle.

Pathogen inoculations were performed when the first wheat leaves were fully expanded. The inoculum was made of spore/ talc mixture at a 1/20 ratio and gently dusted on leaves. Inoculated plants were kept in a dew chamber at $10{ }^{\circ} \mathrm{C}$ for about $24 \mathrm{~h}$, then moved to a growth chamber under a daily cycle of $16 \mathrm{~h}$ of light at $18{ }^{\circ} \mathrm{C}$ and $8 \mathrm{~h}$ of darkness at $10^{\circ} \mathrm{C}$. Plant infection type (IT) were scored based on the scale of 0 , 
$0 ; 0 ;{ }^{+}, 1,1^{+}, 2,2^{+}, 3^{-}, 3,3^{+}$, and 4 , where 0 means no visible infection, 0 ; means necrotic/chlorotic flecks without sporulation, $0 ;^{+}$means necrotic/chlorotic stripes without sporulation, 1 means necrotic/chlorotic stripes with scattered small sporulation, $1^{+}$means necrotic/chlorotic stripes with many small sporulation, 2 means a few moderate sporulation with necrotic/chlorotic flecks, $2^{+}$means many moderate sporulation with necrotic/chlorotic stripes, $3^{-}$means abundant sporulation with necrotic stripes, 3 means abundant sporulation with chlorotic stripes, $3^{+}$means abundant sporulation with chlorosis, and 4 means abundant sporulation without chlorosis (Bariana and McIntosh 1993; Li et al. 2006a). Plants with IT of 0 to $2^{+}$were considered resistant, while those with ITs of $3^{-}$ to 4 were treated as susceptible (Liu 1988; Li et al. 2006a). The susceptible wheat cv. Chinese Spring served as a universal test control.

\section{DNA extraction and bulk segregant analysis}

The parents and $141 \mathrm{~F}_{2}$ plants from Lankao $5 \times$ Chinese Spring 1D monosomic were selected for SSR analysis. Genomic DNA was extracted from leaves of parents and $\mathrm{F}_{2}$ plants using the CTAB method (Riede and Anderson 1996). Based on $\mathrm{F}_{2: 3}$ phenotypic data, resistant and susceptible bulks were made with equal amounts of DNA by ten homozygous resistant and ten homozygous susceptible $F_{2}$ plants, respectively.

\section{Microsatellite marker analysis}

Because the resistance gene in Lankao 5 to Pst race Sun11-11 was cytogenetically located on chromosome 7B by CS monosomic lines, 44 SSR markers specific to wheat chromosome 7B were used to identify polymorphism and to confirm the chromosomal region of the resistance gene in Lankao 5. SSR primer sequences were obtained from Grain Genes (http:// wheat.pw.usda.gov), then synthesized by Sangon Biotech, Inc. (Shanghai, China). The PCR method for each SSR marker followed previous reports (Röder et al. 1998; Somers et al. 2004).

Each $15 \mu \mathrm{L}$ PCR mixture consisted of $1.5 \mu \mathrm{L} 10 \times$ buffer, $2.1 \mu \mathrm{L}$ DNA template $(25 \mathrm{ng} / \mu \mathrm{L}), 0.3 \mu \mathrm{L}$ dNTPs $(2.5 \mathrm{mM}$ each), $1.2 \mu \mathrm{L} \mathrm{MgCl}_{2}(25 \mathrm{mM}), 1.5 \mu \mathrm{L}$ each of the forward and reverse primers ( $10 \mu \mathrm{M}$ each), $0.15 \mu \mathrm{L}$ Taq DNA polymerase

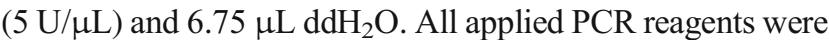
purchased from Sangon Biotech, Inc. PCR amplification was performed using a MJ Research PTC-200 thermal cycler by the following protocol: initial denaturation at $94{ }^{\circ} \mathrm{C}$ for $5 \mathrm{~min}$, followed by 35 cycles of $30 \mathrm{~s}$ each under denaturation at $94{ }^{\circ} \mathrm{C}, 1 \mathrm{~min}$ of annealing at $50-68{ }^{\circ} \mathrm{C}$ (depending on primers), and $45 \mathrm{~s}$ at $72{ }^{\circ} \mathrm{C}$ for extension, then, a finally extension at $72{ }^{\circ} \mathrm{C}$ for $10 \mathrm{~min}$. After amplification, $6 \mu \mathrm{L}$ of formamide loading buffer [98\% formamide, $10 \mathrm{mM}$ EDTA
$(\mathrm{pH} 8.0), 0.5 \%(w / v)$ xylene cyanol, and $0.5 \%(w / v)$ bromophenol blue] was added to the PCR product. About 5 $7 \mu \mathrm{L}$ mixture of the PCR product and loading buffer for each sample was loaded for electrophoresis on $8 \%$ polyacrylamide gel, then visualized by applying silver stain (Bassam et al. 1991; Chen et al. 1998).

\section{Data analysis}

Segregation of the markers and resistance was both tested for fitness to expected ratios using the chi-squared $\left(\chi^{2}\right)$ tests on Excel data analysis program (Microsoft Office 2010). Linkage analysis and map construction of SSR markers and resistance locus were performed with Mapmaker 3.0 (Lander et al. 1987). The recombination rate was converted to map distance (in centimorgan, cM) according to the Kosambi mapping function (Kosambi 1944). The linkage map was drawn using Mapdraw V2.1 (Liu and Meng 2003).

\section{Results}

\section{Resistance evaluation and inheritance analysis of Lankao 5 resistance to stripe rust}

Infection types (ITs) of two races (CYR32 and Sun11-4) on seedlings of Lankao 5 were resistant with no apparent symptoms (IT 0), while those of four Pst races (CYR29, CYR30, CYR31, and Sun11-11) exhibited necrotic flecks without sporulation (IT 0;).The results indicated that Lankao 5 was highly resistant to the test Pst races. In contrast, ITs of six Pst races on Chinese Spring displayed full sporulation and absent in any necrosis (IT 4), indicating Chinese Spring was highly susceptible (Table 1).

The resistance inheritance patterns to wheat stripe rust were controlled by various genes in Lankao 5. In tests on Pst races Sun11-11 and CYR30, $F_{1}$ plants were resistant, while $F_{2}$ populations were segregating as at a ratio $3 \mathrm{R}: 1 \mathrm{~S}$ when tested on Sun11-11and at a ratio 13R:3S when tested on CYR30 (Table 2). The preceding tests indicated that resistance in Lankao 5 to Pst race Sun11-11 was controlled by a dominant gene (temporarily designated $Y r L k$ ), while resistance to Pst race CYR30 was controlled by one dominant gene and one recessive gene, independently.

In tests on Pst races CYR31, CYR32, and Sun11-4, all $\mathrm{F}_{1}$ plants exhibited resistance, while $\mathrm{F}_{2}$ populations segregated at a ratio $15 \mathrm{R}: 1 \mathrm{~S}$ (Table 2), demonstrating that resistance in Lankao 5 to these three races all was controlled by two independently inherited dominant genes.

In terms of resistance to CYR29, all $\mathrm{F}_{1}$ plants were susceptible, while $\mathrm{F}_{2}$ populations segregated at a ratio of $7 \mathrm{R}: 9 \mathrm{~S}$ (Table 2), indicating that resistance to CYR29 in Lankao 5 was controlled by two recessive genes of independent action. 
Table 1 Reaction types of wheat cultivars Lankao 5 and Chinese Spring to different races of the wheat stripe rust fungus, Puccinia striiformis f. sp. tritici (Pst)

\begin{tabular}{lllllll}
\hline Parents & Races & & & & \\
\cline { 2 - 6 } & CYR29 & CYR30 & CYR31 & CYR32 & Sun11-4 & Sun11-11 \\
\hline Lankao 5 & $0 ;$ & $0 ;$ & $0 ;$ & 0 & 0 & $0 ;$ \\
Chinese Spring & 4 & 4 & 4 & 4 & 4 & 4 \\
\hline
\end{tabular}

\section{Chromosomal location of the resistance gene}

To determine the chromosomal location of resistance gene YrLk in Lankao 5 to Pst race Sun11-11, monosomic analysis was applied. Because $\mathrm{F}_{1}$ plants of Lankao $5 \times \mathrm{CS} 3 \mathrm{D}$ monosomic line failed to produce $\mathrm{F}_{2}$ seeds, none further analysis was conducted on their $\mathrm{F}_{2}$ populations. The other 20 crosses of Lankao 5 and CS monosomic lines were examined with race $S u n 11-11$. Each $F_{2}$ population from crosses between Lankao 5 and 19 CS monosomic lines was segregating at a ratio of 3 resistant: 1 susceptible, except the Lankao $5 \times$ CS 7B monosomic line (Table 3 ). The corresponding Lankao $5 \times$ CS 1 D monosomic line (chose by which showed lowest $\chi^{2}$ value on monosomic analysis (Table 3 )) $\mathrm{F}_{3}$ populations was segregating at a ratio of $1 \mathrm{R}: 2 \mathrm{Seg}: 1 \mathrm{~S}$. Plant observations fit the expected ratio, complying with the chi-squared test. For example, Table 3 shows the test results for the $\mathrm{F}_{2}$ Lankao $5 \times \mathrm{CS} 1 \mathrm{D}$ monosomic line population $\left(\chi^{2}=0.36<\chi_{0.05}^{2}=5.99\right)$. The preceding results further supported the conclusion that one dominant gene in

Table 2 Genetic analysis of stripe rust resistance to six races of Puccinia striiformis $\mathrm{f}$.sp. tritici in Lankao $5(\mathrm{P} 1) \times$ Chinese Spring $(\mathrm{P} 2)$ $\mathrm{F}_{1}$ and $\mathrm{F}_{2}$ populations

\begin{tabular}{|c|c|c|c|c|c|c|c|}
\hline \multirow[t]{2}{*}{ Races } & \multirow[t]{2}{*}{ Populations } & \multicolumn{3}{|c|}{ No. of plants } & \multirow{2}{*}{$\begin{array}{l}\text { Expected } \\
\text { ratio }\end{array}$} & \multirow[t]{2}{*}{$\chi^{2}$} & \multirow[t]{2}{*}{$P$ value } \\
\hline & & Total & Res. & Sus. & & & \\
\hline \multirow[t]{3}{*}{ Sun11-11 } & $\mathrm{F}_{1}$ & 8 & 8 & 0 & & & \\
\hline & $\mathrm{F}_{2-1}$ & 178 & 122 & 56 & $3: 1$ & 3.63 & 0.05 \\
\hline & $\mathrm{F}_{2-2}$ & 174 & 139 & 35 & $3: 1$ & 1.96 & 0.14 \\
\hline \multirow[t]{3}{*}{ CYR30 } & $\mathrm{F}_{1}$ & 5 & 5 & 0 & & & \\
\hline & $\mathrm{F}_{2-1}$ & 163 & 131 & 32 & $13: 3$ & 0.04 & 0.77 \\
\hline & $\mathrm{F}_{2-2}$ & 169 & 128 & 41 & $13: 3$ & 3.02 & 0.07 \\
\hline \multirow[t]{3}{*}{ CYR31 } & $\mathrm{F}_{1}$ & 8 & 8 & 0 & & & \\
\hline & $\mathrm{F}_{2-1}$ & 152 & 144 & 8 & $15: 1$ & 0.11 & 0.62 \\
\hline & $\mathrm{F}_{2-2}$ & 145 & 139 & 6 & $15: 1$ & 0.77 & 0.29 \\
\hline \multirow[t]{3}{*}{ CYR32 } & $\mathrm{F}_{1}$ & 9 & 9 & 0 & & & \\
\hline & $\mathrm{F}_{2-1}$ & 163 & 154 & 9 & $15: 1$ & 0.05 & 0.70 \\
\hline & $\mathrm{F}_{2-2}$ & 124 & 112 & 12 & $15: 1$ & 1.94 & 0.11 \\
\hline \multirow[t]{3}{*}{ Sun11-4 } & $\mathrm{F}_{1}$ & 11 & 11 & 0 & & & \\
\hline & $\mathrm{F}_{2-1}$ & 154 & 147 & 7 & $15: 1$ & 0.50 & 0.38 \\
\hline & $\mathrm{F}_{2-2}$ & 176 & 167 & 9 & $15: 1$ & 0.22 & 0.53 \\
\hline \multirow[t]{3}{*}{ CYR29 } & $\mathrm{F}_{1}$ & 8 & 0 & 8 & & & \\
\hline & $\mathrm{F}_{2-1}$ & 135 & 52 & 83 & $7: 9$ & 1.30 & 0.22 \\
\hline & $\mathrm{F}_{2-2}$ & 150 & 61 & 89 & $7: 9$ & 0.46 & 0.45 \\
\hline
\end{tabular}

Lankao 5 conferred resistance to Sun11-11. Segregation of $F_{2}$ plants from crosses of Lankao $5 \times \mathrm{CS} 7 \mathrm{~B}$ monosomic line significantly deviated from the $3 \mathrm{R}: 1 \mathrm{~S}$ ratio $\left(\chi^{2}=43.64>\chi_{0.05}^{2}=3.84\right)$, indicating that chromosome $7 \mathrm{~B}$ carries the resistance gene YrLk.

Table 3 Expected ratios, observed resistant (R) and susceptible (S) $F_{2}$ plants from crosses of resistant cultivar Lankao 5 with Chinese Spring (CS) monosomic lines, inoculated with the Chinese wheat stripe rust Puccinia striiformis f.sp. Tritici race Sun11-11, and probabilities of chisquared test for fit to theoretical ratios

\begin{tabular}{|c|c|c|c|c|c|c|}
\hline \multirow{2}{*}{$\begin{array}{l}\text { Monosome } \\
\text { types }\end{array}$} & \multicolumn{4}{|c|}{ No. of plants ${ }^{\mathrm{b}}$} & \multirow{2}{*}{$\begin{array}{l}\text { Expected } \\
\text { ratio }^{c}\end{array}$} & \multirow[t]{2}{*}{$\chi^{2}$ value $^{\mathrm{d}}$} \\
\hline & Total & Res & Seg & Sus & & \\
\hline $1 \mathrm{~A}$ & 129 & 99 & & 30 & $3: 1$ & 0.13 \\
\hline $2 \mathrm{~A}$ & 113 & 87 & & 26 & $3: 1$ & 0.14 \\
\hline $3 \mathrm{~A}$ & 87 & 60 & & 27 & $3: 1$ & 1.38 \\
\hline $4 \mathrm{~A}$ & 122 & 88 & & 34 & $3: 1$ & 0.39 \\
\hline $5 \mathrm{~A}$ & 100 & 78 & & 22 & $3: 1$ & 0.33 \\
\hline $6 \mathrm{~A}$ & 59 & 48 & & 11 & $3: 1$ & 0.95 \\
\hline $7 \mathrm{~A}$ & 109 & 83 & & 26 & $3: 1$ & 0.03 \\
\hline 1B & 111 & 81 & & 30 & $3: 1$ & 0.15 \\
\hline $2 \mathrm{~B}$ & 107 & 78 & & 29 & $3: 1$ & 0.15 \\
\hline $3 \mathrm{~B}$ & 69 & 50 & & 19 & $3: 1$ & 0.12 \\
\hline 4B & 96 & 69 & & 27 & $3: 1$ & 0.35 \\
\hline $5 \mathrm{~B}$ & 114 & 84 & & 30 & $3: 1$ & 0.05 \\
\hline $6 \mathrm{~B}$ & 116 & 91 & & 25 & $3: 1$ & 0.56 \\
\hline $7 \mathrm{~B}$ & 121 & 110 & & 11 & $3: 1$ & $15.50 * *$ \\
\hline $1 \mathrm{D}$ & 141 & 107 & & 34 & $3: 1$ & 0.02 \\
\hline $2 \mathrm{D}$ & 105 & 84 & & 21 & $3: 1$ & 1.15 \\
\hline $4 \mathrm{D}$ & 87 & 69 & & 18 & $3: 1$ & 0.65 \\
\hline $5 \mathrm{D}$ & 103 & 76 & & 27 & $3: 1$ & 0.03 \\
\hline $6 \mathrm{D}$ & 68 & 49 & & 19 & $3: 1$ & 0.18 \\
\hline $7 \mathrm{D}$ & 84 & 64 & & 20 & $3: 1$ & 0.02 \\
\hline All $\mathrm{F}_{2}$ plants & 2041 & 1555 & 70 & 486 & $3: 1$ & 1.47 \\
\hline Lankao 5/CS $1 \mathrm{D} \mathrm{F}_{3}{ }^{\mathrm{a}}$ & 141 & 33 & 70 & 38 & $1: 2: 1$ & 0.36 \\
\hline
\end{tabular}

${ }^{\mathrm{a}}$ The Lankao 5/4CS $1 \mathrm{D} \mathrm{F}_{3}$ lines, which were used to construct the mapping population were derived from Lankao $5 / \mathrm{CS} 1 \mathrm{D} \mathrm{F}_{2}$ plants

${ }^{\mathrm{b}}$ The $\mathrm{F}_{2}$ ratios are for resistant and susceptible plants, and the $\mathrm{F}_{3}$ ratios are for homozygous resistant, segregating and homozygous susceptible lines

${ }^{\mathrm{c}}$ The segregating lines included resistant and susceptible plants

${ }^{\mathrm{d}}$ For $\mathrm{F}_{2}$ ratios $\chi_{0.05}^{2}=3$. 84, For $\mathrm{F}_{3}$ ratios $\chi_{0.05}^{2}=5.99$

** indicated significance level: $P<0.01$ 


\section{Molecular mapping of the stripe rust resistance gene}

Forty-four SSR markers covering chromosome 7B were screened on Lankao 5, resistant bulk, the susceptible parent Chinese Spring, and susceptible bulk to identify those associated with the $Y r L k$ locus. Five markers, Xwmc476, Xbarc267, Xwmc396, Xgwm131, and Xwmc517, generated polymorphism bands between the resistant and susceptible bulks, as well as their parents. All of the five markers are located on the long arm of chromosome 7B, based on the wheat consensus SSR map (Somers et al. 2004).

These five SSR markers were further used to genotype the $141 \mathrm{~F}_{2: 3}$ plants. The results showed that each of the five markers was co-dominant and well fitted a segregating ratio of 1 (homozygous resistant parental allele):2 (heterozygous allele): 1 (susceptible parental allele), indicating each marker is a single locus and reliable for use to construct a linkage map (Table 4). Linkage analysis showed that resistance gene $Y r L k$ was linked with the five SSR loci; therefore, $Y r L k$ was also located on the long arm of chromosome 7B. A linkage map was composed of YrLk locus and five SSR loci, spanning $21.6 \mathrm{cM}$. The marker order obtained for the five SSRs was compatible with that determined by Somers et al. (2004). The two closest-flanking loci of $Y r L k$ were Xwmc396 and Xbarc267, with genetic distances of 3.3 and $4.4 \mathrm{cM}$, respectively (Fig. 1). For example, Fig. 2 displays the segregation of marker alleles in the $\mathrm{F}_{2: 3}$ populations of the two closest-flanking markers. Xwmc396 and Xbarc267 are located near the centromere, based on wheat SSR maps (Somers et al. 2004), delineating the position of $Y r L k$ as proximal to the centromere of chromosome 7BL.

\section{Discussion}

In addition to $Y r L k$, seven officially named $Y r$ genes $(Y r 2, Y r 6$, Yr39, Yr52, Yr59, Yr63, and Yr67 reported by McIntosh et al. 1998; El-Bedewy and Robbelen 1982; Lin and Chen 2007; Ren et al. 2012; Zhou et al. 2014; McIntosh et al. 2014), five temporarily named $\mathrm{Yr}$ genes (YrZh84, YrC591, YrShan515,

Table 4 Observed molecular marker numbers and alleles of Lankao 5 (A), Chinese Spring (B) and their heterozygous $(\mathrm{H})$ progeny in $\mathrm{F}_{2}$ population from Lankao $5 \times$ Chinese Spring, and probabilities of chi-squared test of fit to theoretical ratios

\begin{tabular}{|c|c|c|c|c|c|c|}
\hline \multirow[t]{2}{*}{ Markers } & \multicolumn{3}{|c|}{ No. of $F_{2}$ plants } & \multirow[t]{2}{*}{ Expected ratio } & \multirow[t]{2}{*}{$\chi^{2}$} & \multirow[t]{2}{*}{$P$ value } \\
\hline & A & $\mathrm{H}$ & B & & & \\
\hline Xwmc476 & 33 & 70 & 38 & $\mathrm{~A}: \mathrm{H}: \mathrm{B}=1: 2: 1$ & 0.36 & 0.83 \\
\hline Xbarc267 & 36 & 72 & 33 & $\mathrm{~A}: \mathrm{H}: \mathrm{B}=1: 2: 1$ & 0.19 & 0.91 \\
\hline Xwmc396 & 32 & 79 & 40 & $\mathrm{~A}: \mathrm{H}: \mathrm{B}=1: 2: 1$ & 1.17 & 0.56 \\
\hline Xgwm 131 & 34 & 73 & 34 & $\mathrm{~A}: \mathrm{H}: \mathrm{B}=1: 2: 1$ & 0.18 & 0.92 \\
\hline Xwmc517 & 34 & 77 & 30 & $\mathrm{~A}: \mathrm{H}: \mathrm{B}=1: 2: 1$ & 1.43 & 0.49 \\
\hline
\end{tabular}

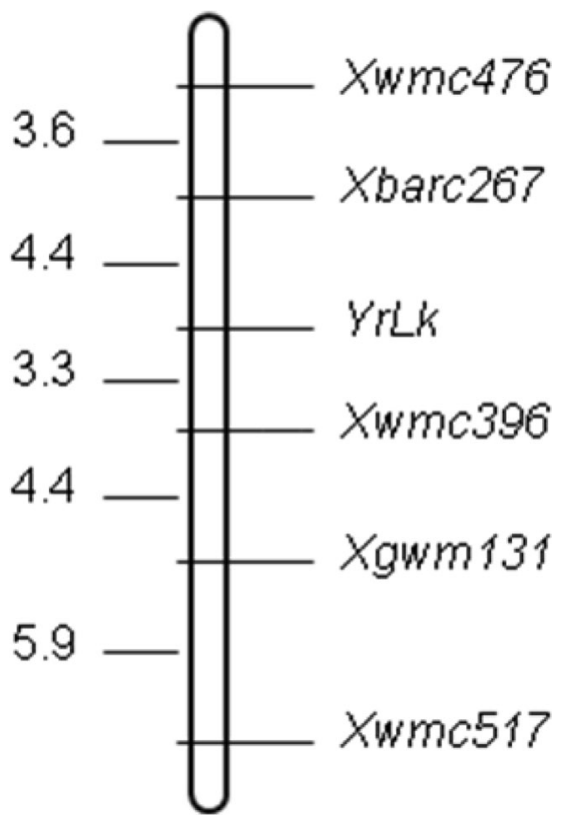

Fig. 1 Linkage map of stripe rust resistance gene $Y r L k$

yrMY37, and $\mathrm{YrSu}-1$, reported by Li et al. 2009; Li et al. 2006b; Zhang et al. 2011; Ren et al. 2015; Yan et al. 2009), and 11 quantitative-trait loci (QTL) (Maccaferri et al. 2015) have been reported on chromosome 7B. Yr6 and Yr63 are located on the short arm of chromosome 7B (El-Bedewy and Robbelen 1982; McIntosh et al. 2014), a different chromosomal arm from YrLk. The Yr6 near-isogenic line AvSYr6NIL and $\operatorname{Yr} 6$ carrier cultivars Heines Peko and Heines Kolben (Calonnec et al. 1997) were susceptible to Pst race Sun11-11 in our greenhouse test, while $Y r L k$ is resistant. YrLk should be different from $Y r 6$.

Yr39, Yr52, and Yr59 are high-temperature adult-plant (HTAP) resistance genes, which are susceptible to Pst races at the seedling stage (Lin and Chen 2007; Ren et al. 2012; Zhou et al. 2014). Yr52, Yr59, Yr67, YrZh84, and YrC591 are located on the telomere of the long arm of chromosome 7B ( $\mathrm{Li}$ et al. 2006b; McIntosh et al. 2014; Ren et al. 2012; Zhou et al. 2014; Xu et al. 2014), while YrLk is proximal to the centromere of 7B. Based on the resistance type and chromosome location, $Y r L k$ may be different from these four genes.

In 1962, Yr2 was first reported as located on chromosome 7B in Heines VII (McIntosh et al. 1998) and was later mapped on $7 \mathrm{BL}$, with a genetic distance to Xwmc364 of $5.6 \mathrm{cM}$ (Lin et al. 2005). Xwmc364 does not exhibit polymorphism between Lankao 5 and Chinese Spring, and cannot be mapped in our population. $\mathrm{YrSu}-1$ was reported on chromosome 7BL with the genetic distance from Xwmc396 to $\mathrm{YrSu}-1$ of $21.1 \mathrm{cM}$ (Yan et al. 2009). The distance from YrLk to Xwmc396 is $3.3 \mathrm{cM}$. When Heines VII was tested with Sun11-11 at the seedling stage in greenhouse condition, it was susceptible (IT 3-4), and the carrier cultivar of $\mathrm{YrSu}-1$, Suwon11, was susceptible to Sun11-11 (Chen et al. 2009). The rust response reaction 
Fig. 2 PCR profiles for the $\mathrm{F}_{2}$ segregated population and parents, amplified by the YrLk flanking markers Xbarc267 (a) and Xwmc396 (b) in polyacrylamide gel. $M$ DNA size ladder, $\operatorname{Pr}$ resistant parent Lankao 5, $P$ s susceptible parent Chinese Spring, $B r$ resistant DNA bulk, $B s$ susceptible DNA bulk, $R$ resistant plant, $S$ susceptible plant, $H$ heterozygous resistant plants

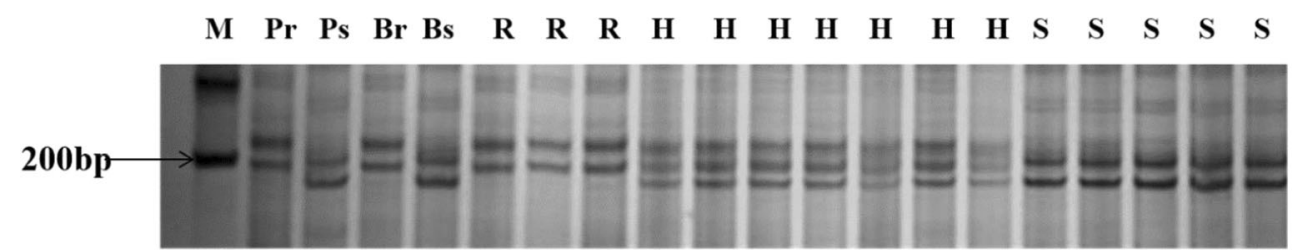

a

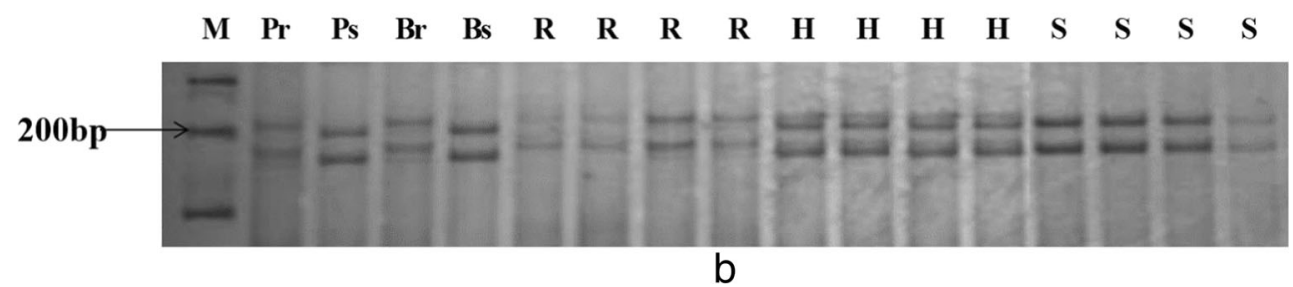

and relative chromosomal position of three genes suggested that $Y r 2$ and $Y r S u-1$ are different from $Y r L k$.

YrShan515 was identified in Chinese landrace Shan 515, conferring resistance to Pst race Sun11-4 (Zhang et al. 2011). The genetic distances of flanking markers Xbarc267 and
Xwmc653 to YrShan515 are 3.0 and $3.4 \mathrm{cM}$, respectively (Zhang et al. 2011), while the genetic distance from Xbarc267 to YrLk is $4.4 \mathrm{cM}$. It appears that YrShan515 and YrLk are genetically proximal. However, resistance by Shan 515 to race Sun11-11 is reported as controlled by two

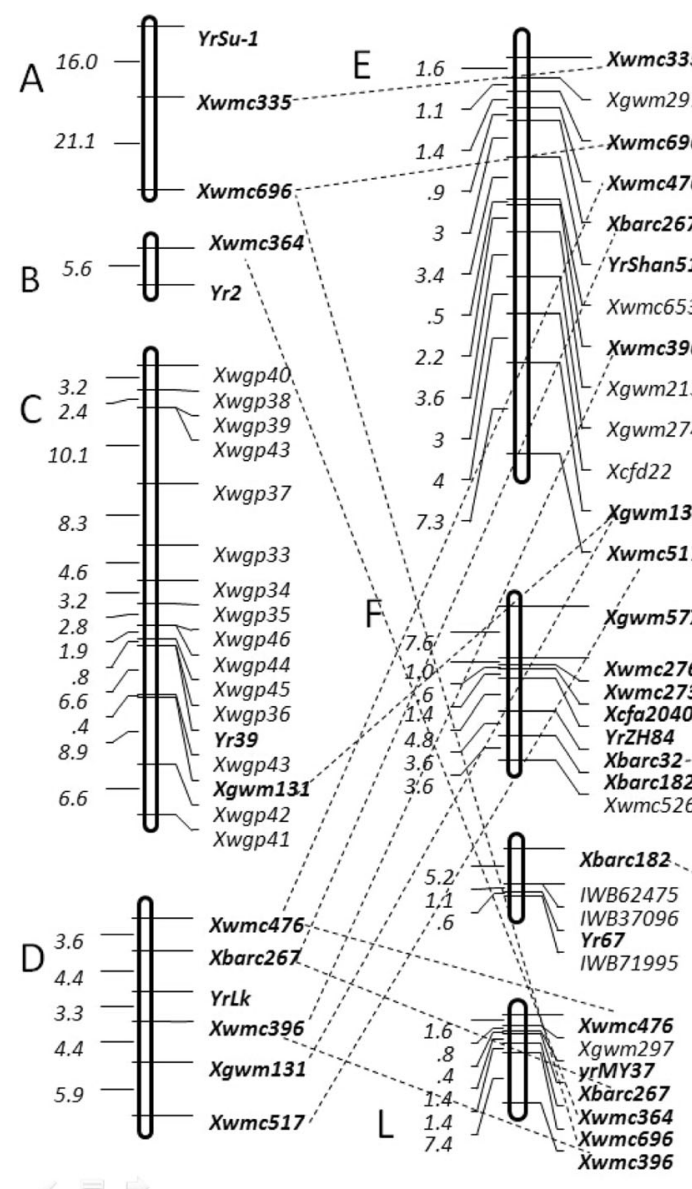

Fig. 3 Linkage maps for stripe rust resistant genes on the long arm of chromosome 7B and comparisons with the consensus map. The dashed lines connect common markers on different maps. Genetic map showing the relative genetic locations of $\operatorname{YrLk}(D)$ with other $Y r$ genes in this study. Yr2 in Lin et al. (2005) (B), Yr39 in Lin and Chen (2007) (C), Yr52 in Ren et al. (2012) (I), Yr59 in Zhou et al. (2014) (J), Yr67 in McIntosh et al.

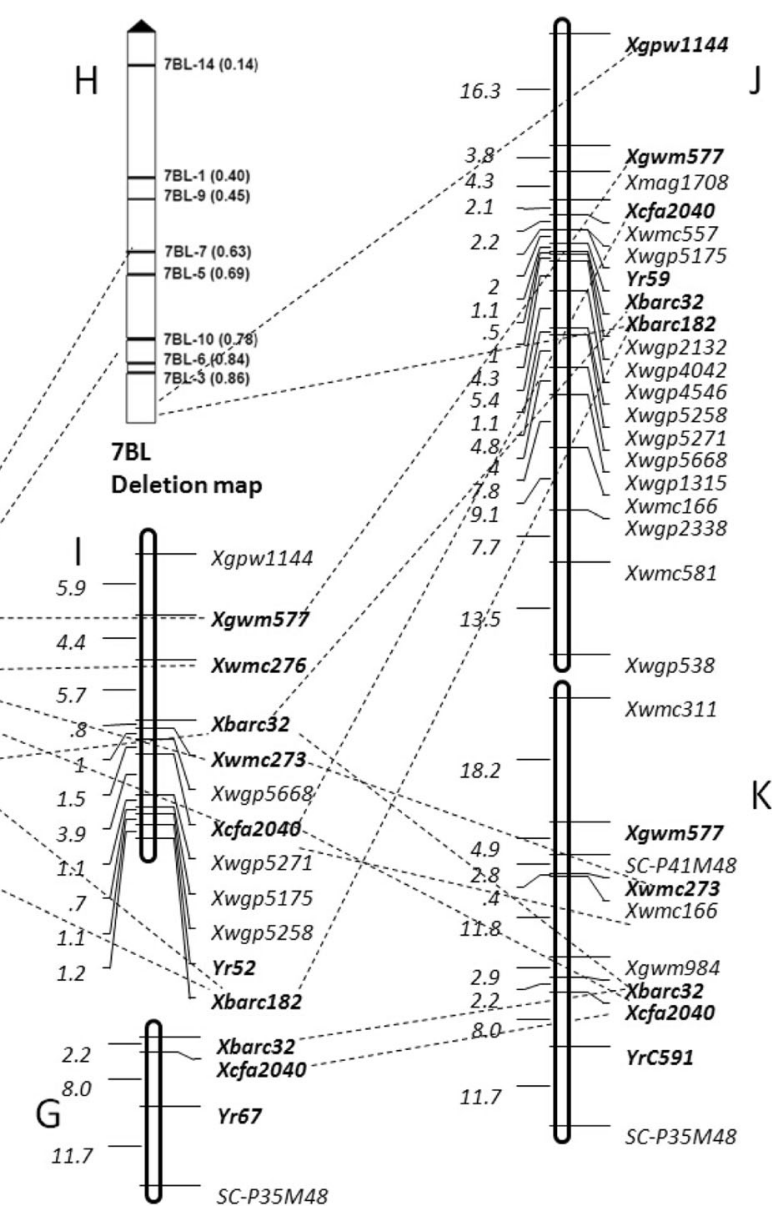

(2014) $(G), Y r C 591$ in Xu et al. (2014) $(K), Y r Z h 84$ in Li et al. (2006b) (F), YrSu-1 in Yan et al. (2009) (A), YrShan515 in Zhang et al. (2011) (E), and $y r Y M 37$ in Ren et al. (2015) on chromosome 7BL, and the shared markers in each linkage map and the corresponding chromosomal bin locations $(H)$ 
recessive genes (Zhang 2010), different from results for YrLk in this study. Furthermore, Shan 515 is susceptible to race CYR32 while Lankao 5 is resistant to CYR32. These results indicate high likelihood that $Y r L k$ and $Y r S h a n 515$ are different genes.

yrMY37 was identified in Chinese wheat cultivar Mianmai 37, conferring resistance to Pst race v26 (Ren et al. 2015). The genetic distances of flanking markers Xgwm 297 and Xbarc267 to $y r M Y 37$ are 0.78 and $0.38 \mathrm{cM}$, respectively (Ren et al. 2015), while the genetic distance from Xbarc267 to $Y r L k$ is $4.4 \mathrm{cM}$. But $y r M Y 37$ was reported as a recessive gene, while $Y r L k$ is a dominant gene. The reaction type of Mianmai 37 (yrMY37) to race CYR32 is 1, and to CYR31 is 2 (Ren et al. 2015), while reaction type of Lankao 5 to race CYR32 is 0 , and to CYR31 is 0:. These results indicate that $Y r L k$ and $y r M Y 37$ are different genes.

The above cultivars content of $\mathrm{Yr}$ genes originate in very different places. Yr2, Yr6, Yr63, and Yr67 are derived from European cultivars. $\operatorname{Yr} 39$ was identified from the US cultivar Alpowa (Lin and Chen 2007). The carrier cultivars for $\operatorname{Yr} 52$, Yr59, and YrC591 originate in Pakistan, Iraq, and India, respectively (Ren et al. 2012; Zhou et al. 2014; Li et al. 2009). YrZhou 84 was identified from wheat cultivar, Zhou8425B. The stripe rust resistance in Zhou8425B originated in an Italian cultivar Milan ( $\mathrm{Li}$ et al. 2006b). $\mathrm{YrSu}-1$ is derived from a Korean cultivar Suwon 11. Shan 515, YrShan 515 gene carrier, is a wheat landrace from Shaanxi, China (Zhang 2010). $y r M Y 37$ is derived from Chinese wheat cultivar Mianmai 37.

Overall, $Y r L k$ shows great differences in various aspects from other $\mathrm{Yr}$ genes on chromosome 7B, including chromosomal position, origin of gene carrier, and resistance against Pst races. It is very likely that $Y r L k$ is a novel, effective stripe rust resistance gene. Figure 3 shows the relative locations of $\operatorname{YrLk}(\mathrm{D})$ and $\operatorname{Yr2}(\mathrm{B}), \operatorname{Yr} 39$ (C), $\operatorname{Yr} 52$ (I), $\operatorname{Yr} 59$ (J), $\operatorname{Yr} 67$ (G), YrC591 (K), YrZh84 (F), YrSu-1 (A), YrShan515 (E), and $y r M Y 37$ (L) on 7BL compared with common markers on the chromosome 7BL linkage maps.

Landraces are important genetic sources and may harbor valuable stripe rust resistance (Sthapit et al. 2014; Kertho et al. 2015). Wang et al. (2012) identified over 200 stripe rust resistance landraces from 28 countries and developed 70 germplasms in the background of the elite spring wheat cultivar 'Avocet', and these germplasms have various resistance types to the Pst populations in the USA. Most of these germplasm lines have high resistance to current Chinese Pst races (Zhou et al. 2015). The resistance genes $\operatorname{Yr} 45$, Yr52, Yr53, $Y r 59$, and $Y r 62$ in these landraces were mapped with molecular markers ( $\mathrm{Li}$ et al. 2011; Xu et al. 2013; Ren et al. 2012; Zhou et al. 2014; Lu et al. 2014). Some Chinese wheat landraces play important roles in the stripe rust epidemic areas where modern cultivars are unable to adapt to the local ecosystem, such as Pingyan 50, Caoxuan 5, and Baidatou (Lan et al. 2010; Zhou et al. 2015; Ma et al. 2015). However, most landraces have poor agronomic traits or low yield potential and are thus not suited to modern cultivation conditions. It is necessary to develop techniques to transfer desirable traits, such as stripe rust resistance, from these landraces to new cultivars, while excluding negative traits. Undoubtedly, the closely linked molecular markers of resistance genes constitute an efficient tool for selection during wheat breeding. The genomic region of $Y r L k$ is expressed as a gene hotspot, which allows gene exchange to occur. As a result, combining different $\mathrm{Yr}$ genes into a new germplasm may prove to be relatively easy.

In this study, results confirm that Lankao 5 is resistant to most of the currently prevalent Chinese Pst races at the seedling stage. At least four genes in Lankao 5 conferring resistance to stripe rust were genetically determined, one dominant gene (YrLk) resistant to race Sun11-11, one dominant gene and one recessive gene to CYR30, two dominant genes resistant to races CYR31 and CYR32 (one of which maybe $Y r L k$ ), and two recessive genes resistant to CYR29. Lankao 5 is an excellent stripe rust resistance wheat landrace, which is one of the best candidates for disease resistance; furthermore, the closely flanking markers, Xwmc396 and Xbarc267, of $Y r L k$ allow $Y r L k$ for high efficient use in marker-assisted selection for stripe rust resistance in breeding programs.

Acknowledgements The authors are grateful for critical review of the manuscript by Dr. Meinan Wang. This research was supported by the Scientific Research Foundation for Returned Overseas Chellonese Scholars (2015 Qinghai, Hou Lu), the National Natural Science Foundation of China (31360421, 31660513), and the National Natural Science Foundation of Qinghai, China (2016-HZ-810).

Open Access This article is distributed under the terms of the Creative Commons Attribution 4.0 International License (http:// creativecommons.org/licenses/by/4.0/), which permits unrestricted use, distribution, and reproduction in any medium, provided you give appropriate credit to the original author(s) and the source, provide a link to the Creative Commons license, and indicate if changes were made.

\section{References}

Bariana HS, McIntosh RA (1993) Cytogenetic studies in wheat XV. Location of rust resistance genes in VPM1 and their genetic linkage with other disease resistance genes in chromosome $2 \mathrm{~A}$. Genome 36 : 476-482

Bassam BJ, Caetano-Anolles G, Gresshoff PM (1991) Fast and sensitive silver staining of DNA in polyacrylamide gels. Anal Biochem 196: 80-83

Calonnec A, Johnson R, De Vallavieille-Pope C (1997) Genetic analysis of resistance to Puccinia striiformis in the wheat differential cultivars Heines VII, Heines Peko and Strubes Dickkopf. Plant Pathol $46: 373-386$

Chen XM (2005) Epidemiology and control of stripe rust [Puccinia striiformis f. sp. tritici] on wheat. Can J Plant Pathol 27:314-337

Chen WQ, Wu LR, Liu TG, Xu SC (2009) Race dynamics, diversity, and virulence evolution in Puccinia striformis f. sp. tritici, the causal 
agent of wheat stripe rust in China from 2003 to 2007. Plant Dis 93: 1093-1101

Chen XM, Line RF, Leung H (1998) Genome scanning for resistancegene analogs in rice, barley, and wheat by high-resolution electrophoresis. Theor Appl Genet 97:345-355

Cheng P, Xu LS, Wang MN, See DR, Chen XM (2014) Molecular mapping of genes $\operatorname{Yr} 64$ and $\operatorname{Yr} 65$ for stripe rust resistance in hexaploid derivatives of durum wheat accessions PI 331260 and PI 480016. Theor Appl Genet 127:2267-2277

Cheng Y, Song W, Liu ZY, Xie CJ, Ni ZF, Peng HR, Nie XL, Yang ZM, Sun QX (2006) Microsatellite markers for a yellow rust resistant gene in wheat cultivar Guinong 21. Acta Agronom Sin 32:18671872 (In Chinese)

El-Bedewy R, Robbelen G (1982) Chromosomal location and change of dominance of a gene for resistance against yellow rust, Puccinia striiformis West., in wheat, Triticum aestivum L. Zeitschrift fur Pflanzenzuchtung 89:145-157

Han DJ, Wang N, Jiang Z, Wang QL, Wang XJ, Kang ZS (2012) Characterization and inheritance of resistance to stripe rust in the wheat line Guinong 775. Hereditas 34:1607-1613 (In Chinese)

Han DJ, Wang QL, Zhang L, Wei GR, Zeng QD, Zhao J, Wang XJ, Huang LL, Kang ZS (2010) Evaluation of resistance of current wheat cultivars to stripe rust in northwest China, north China and the middle and lower reaches of Changjiang river epidemic area. Sci Agric Sin 43:2889-2896 (In Chinese)

Hou L, Ma DF, Hu ML, He MM, Lu Y, Jing JX (2013) Genetic analysis and molecular mapping of an all-stage stripe rust resistance gene in Triticum aestivum-Haynaldia villosa translocation line V3. J Integr Agr 12:2197-2208

Kertho A, Mamidi S, Bonman JM, McClean PE, Acevedo M (2015) Genome-wide association mapping for resistance to leaf rust and stripe rust in winter-habit hexaploid wheat landraces. PLoS One 10:e129580. doi:10.1371/journal.pone.0129580

Kosambi DD (1944) The estimation of map distances from recombination values. Annals of Eugenics 12:172-175

Lan CX, Liang SS, Zhou XC, Zhou G, Lu QL, Xia XC, He ZH (2010) Identification of genomic regions controlling adult-plant stripe rust resistance in Chinese landrace Pingyuan 50 through bulked segregant analysis. Phytopathology 100:313-318

Lander ES, Green P, Abrahamson J, Barlow A, Daly MJ, Lincoln SE, Newburg I (1987) MAPMAKER: an interactive computer package for constructing primary genetic linkage maps of experimental and natural populations. Genomics 1:174-181

Li ZQ, Zeng SM (2002) Wheat rust in China. Chinese Agricultural Press, Beijing. p 41-50, 164-173. (In Chinese)

Li GQ, Li ZF, Yang WY, Zhang Y, He ZH, Xu SC, Singh RP, Qu YY, Xia $\mathrm{XC}$ (2006a) Molecular mapping of stripe rust resistance gene $\mathrm{YrCH} 42$ in Chinese wheat cultivar Chuanmai 42 and its allelism with $Y r 24$ and $Y r 26$. Theor Appl Genet 112:1434-1440

Li ZF, Zheng TC, He ZH, Li GQ, Xu SC, Li XP, Yang GY, Singh RP, Xia $\mathrm{XC}$ (2006b) Molecular tagging of stripe rust resistance gene $\mathrm{YrZH} 84$ in Chinese wheat line Zhou 8425B. Theor Appl Genet 112:10981103

Li Y, Niu YC, Chen XM (2009) Mapping a stripe rust resistance gene YrC591 in wheat variety C591 with SSR and AFLP markers. Theor Appl Genet 118:339-346

Li Q, Chen XM, Wang MN, Jing JX (2011) Yr45, a new wheat gene for stripe rust resistance on the long arm of chromosome 3D. Theor Appl Genet 122:189-197

Li Q, Li GB, Yue WY, Du JY, Yang LJ, Kang ZS, Jing JX, Wang BT (2016) Pathogenicity changes of wheat stripe rust fungus and disease resistance of wheat cultivars (lines) in Shaanxi province during 2002-2014. Acta Phytophyl Sin 46:374-383

Lin F, Chen XM (2007) Genetics and molecular mapping of genes for race-specific all-stage resistance and non-race-specific high- temperature adult-plant resistance to stripe rust in spring wheat cultivar Alpowa. Theor Appl Genet 114:1277-1287

Lin F, Xu SC, Zhang LJ, Miao Q, Zhai Q, Li N (2005) SSR marker of wheat stripe rust resistance gene $Y r 2$. J Triticeae Crop 25:17-19 (In Chinese)

Line RF (2002) Stripe rust of wheat and barley in North America: a retrospective historical review. Annu Rev Phytopathol 40:75-118

Liu RH, Meng JL (2003) Map Draw: a Microsoft Excel macro for drawing genetic linkage maps based on given genetic linkage data. Hereditas 25:317-321 (In Chinese)

Liu XK (1988) A preliminary study on the inheritance of resistance to stripe rust in wheat. Acta Phytophyl Sin 15:33-39 (In Chinese)

Lu Y, Wang MN, Chen XM, See DR, Chao SM, Jing JX (2014) Mapping of Yr62 and a small-effect QTL for high-temperature adult-plant resistance to stripe rust in spring wheat PI192252. Theor Appl Genet 127:1449-1459

Ma DF, Li Q, Tang MS, Chao KX, Li JC, Wang BT, Jing JX (2015) Mapping of gene conferring adult-plant resistance to stripe rust in Chinese wheat landrace Baidatou. Mol Breeding 35:157-165

Maccaferri M, Zhang JL, Bulli P, Abate Z, Chao SM, Cantu D, Bossolini E, Chen XM, Pumphrey M, Dubcovsky J (2015) A genome-wide association study of resistance to stripe rust (Puccinia striiformis $\mathrm{f}$. sp. tritici) in a worldwide collection of hexaploid spring wheat (Triticum aestivum L.) G3: Genes Genom Genet 5:449-465

McIntosh RA, Hart GE, Devos KM, Gale MD, Rogers WJ, Slinkard A E (1998) Catalogue of gene symbols for wheat. In: Proceedings of the 9th International Wheat Genetics Symposium. vol. 5. University Extension Press, University of Saskatchewan, Saskatoon, p 1.125.

McIntosh RA, Dubcovsky J, Rogers WJ, Morris C, Appels R, Xia XC (2014) Catalogue of gene symbols for wheat: 2013-2014 supplement. http://www.shigen.nig.ac.jp/wheat/komugi/genes/ symbolClassList.jsp

Riede CR, Anderson JA (1996) Linkage of RFLP markers to an aluminum tolerance gene in wheat. Crop Sci 36:905-909

Ren Q, Liu HJ, Chen Y, Xu SC, He MZ, Xin ZY, Zhang ZY (2010) Molecular tagging of a stripe rust resistance gene in a Triticum durum-Aegilops squarrosa synthetic wheat CI191. Acta Agronom Sin 36:721-727 (In Chinese)

Ren RS, Wang MN, Chen XM, Zhang ZJ (2012) Characterization and molecular mapping of $Y r 52$ for high-temperature adult-plant resistance to stripe rust in spring wheat germplasm PI183527. Theor Appl Genet 125:847-857

Ren Y, Li SR, Xia XC, Zhou Q, He YJ, Wei YM, Zheng YL, He ZH (2015) Molecular mapping of a recessive stripe rust resistance gene yrMY37 in Chinese wheat cultivar Mianmai 37. Mol Breeding 35: 97

Röder MS, Korzun V, Wendehake K, Plaschke J, Tixier MH, Leroy P, Ganal MW (1998) A micro-satellite map of wheat. Genetics 149: 2007-2023

Somers DJ, Isaac P, Edwards K (2004) A high-density microsatellite consensus map for bread wheat (Triticum aestivum L.) Theor Appl Genet 109:1105-1114

Sthapit J, Newcomb M, Bonman JM, Chen XM, See DR (2014) Genetic diversity for stripe rust resistance in wheat landraces and identification of accessions with resistance to stem rust and stripe rust. Crop Sci 54:2131-2139

Wan AM, Wu LR, Jia QZ, Jin SL, Wang BT, Yao G, Yang JX, Yuan ZY, Bi YQ (2003) Pathogenic changes of stripe rust fungus of wheat in China during 1997-2001. Acta Agronom Sin 33:261-266 (In Chinese)

Wan AM, Zhao ZH, Chen XM, He ZH, Jin SL, Jia QZ, Yao G, Yang JX, Wang BT, Li GB, Bi YQ, Yuan ZY (2004) Wheat stripe rust epidemic and virulence of Puccinia striiformis f. sp. tritici in China in 2002. Plant Dis 88:896-904

Wan AM, Chen XM, He ZH (2007) Stripe rust in China. Aust J Agric Res 58:605-619 
Wang LF, Ma JX, Zhou RH, Wang XM, Jia JZ (2002) Molecular tagging of the yellow rust resistance gene $\mathrm{Yr} 10$ in common wheat, PI178383 (Triticum aestivum L.) Euphytica 124:71-73

Wang BT, Li GB, Li Q, Wang F, Kang ZS (2007) Population changes of stripe rust fungus of wheat in Shaanxi province during 2001-2005. Journal of Northwest A \& F University (Nat Sci Ed) 35:209-216 (In Chinese)

Wang CM, Zhang YP, Han DJ, Kang ZS, Li GP, Cao AZ, Chen PD (2008) SSR and STS markers for wheat stripe rust resistance gene Yr26. Euphytica 159:359-366

Wang LM, Zhang ZY, Liu HJ, Xu SC, He MZ, Liu HX, Veisz O, Xin ZY (2009) Identification, gene postulation and molecular tagging of a stripe rust resistance gene in synthetic wheat CI142. Cereal Res Commun 37:209-215

Wang MN, Chen XM, Xu LS, Cheng P, Bockelman HE (2012) Registration of 70 common spring wheat germplasm lines resistant to stripe rust. Journal of Plant Registrations 6(1):104-110

Wellings CR (2011) Global status of stripe rust: a review of historical and current threats. Euphytica 179:129-141

Xu LS, Wang MN, Cheng P, Kang ZS, Hulbert S, Chen XM (2013) Molecular mapping of $Y r 53$, a new gene for stripe rust resistance in durum wheat accession PI480148 and its transfer to common wheat. Theor Appl Genet 126:523-533

Xu HX, Zhang J, Zhang P, Qie YM, Niu YC, Li HJ, Ma PT, Xu YF, An DG (2014) Development and validation of molecular markers closely linked to the wheat stripe rust resistance gene YrC591 for markerassisted selection. Theor Appl Genet 198:317-323

Yan GP, Chen XM, Line RF, Wellings CR (2003) Resistance gene analog polymorphism markers co-segregating with the $\operatorname{Yr} 5$ gene for resistance to wheat stripe rust. Theor Appl Genet 106:636-643
Yan YD, Lu LL, Zhou XL, Wang MN, Jing JX (2009) The genetic analysis and SSR molecular markers of stripe rust resistance gene in Chinese differential cultivar Suwon 11. J Plant Protect 36:285286 (In Chinese)

Yang ZM, Xie CJ, Sun QX (2003) Situation of sources of stripe rust resistant of wheat in the post-CYR32 era in China. Acta Agronom Sin 29:161-168 (In Chinese)

Yaniv E, Raats D, Ronin Y, Korol AB, Grama A, Briana H, Dubcovsky J, Schulman AH, Fahima T (2015) Evaluation of marker-assisted selection for stripe rust resistance gene $\operatorname{Yr} 15$, introgressed from wild emmer wheat. Mol breeding 35:43

Zhang H, Ren ZL, Hu YG, Wang CY, Ji WQ (2010) Characterization of wheat stripe rust resistance genes in Shaanmai 139. Acta Agronom Sin 36:109-114 (In Chinese)

Zhang SY, Xu ZQ, Wang R, Li Q, Yao Q, JING JX (2011) Genetics and molecular mapping of stripe rust resistance gene YrShan 515 in Chinese wheat cultivar Shan 515. J Integr Agr 10:553-559

Zhang SY (2010) Genetic analysis of stripe rust resistance gene in wheat varieties Shan515, Xiaoyan016 and Xiaoyan9366. M.S. Thesis, Northwest A\&F University, page 24-25. (In Chinese)

Zhou XL, Wang MN, Chen XM, Lu Y, Kang ZS, Jing JX (2014) Identification of $\operatorname{Yr} 59$ conferring high temperature adult plant resistance to stripe rust in wheat germplasm PI178759. Theor Appl Genet 127:935-945

Zhou XL, Zhan GM, Huang LL, Han DJ, Kang ZS (2015) Evaluation of resistance to stripe rust in eighty abroad spring wheat germplasms. Sci Agric Sin 48:1518-1526 (In Chinese) 